and yet the absolute losses they occasioned were so small as to have little influence on the totals used in the computation.

On the whole, weighing these and other factors of the problem as well as I am able, I am disposed to adhere to the estimate, not, indeed, claiming for it a high measure of precision, but regarding it as a fair approximation to the truth, and possibly as good as may be derived from the available facts.

It is needless to carry further the diseussion of insurance rates. Its purpose has been served in showing that the earthquake risk to buildings in California is comparable with the fire risk and equally worthy of serious consideration. There is no present question of earthquake insurance, of which the function would be merely to distribute earthquake losses, but there is a question of the prevention of earthquake damage.

Earthquake damage is at least as preventable as fire damage. It is possible so to construct houses that they will neither collapse nor otherwise be vitally injured by such shocks as have visited California in the past. In a house so built there will be small danger from earthquake-started fires because they will be both accessible and quickly detected. It is wreckage that prevents the prompt extinguishment of the initial blaze. In a house so built there will be little damage to furniture, merchandise and other valuable contents. With houses so built the life risk will become a vanishing quantity, for practically all earthquake casualties are directly due to the failure of buildings. And in a community thus protected in life and property the terror of the mysterious unheralded temblor-a factor far outweighing the actual personal peril-will gradually wear away.

In saying that earthquake damage is preventable I would not be understood to imply that the subject of earthquake-proof construction is at all adequately developed. Competent modes of construction are known, but the best modes, the most economic modes, the modes best adapted to American materials and conditions remain to be determined, and there is much need of investigation.

It should be the policy of the people and state of California to see that the necessary investigations are made, and that the results are embodied in the building regulations of all cities as well as in the entire building practise of the state. And, in order that the methods of construction may be properly adjusted to the very unequal local requirements, provision should be made for a seismic survey and the mapping of tracts of special earthquake danger.

\section{G. K. GILberT}

\section{JEAN ALBERT GAUDRY ${ }^{1}$}

From time to time as honored chieftains fall in the front ranks of the world's intellectual forces that are making for scientific progress, and bent on the conquest of new realms of knowledge, it befits men of a younger generation to take note of the passing of these heroes, these veteran standard-bearers who now rest from their labors, leaving a splendid memorial of their lifework behind them. Upon such occasions it is well to call to mind some of the more notable achievements of these patient searchers after truth, and to bethink ourselves what manner of men were they who contributed largely to widening the bounds of human understanding, whose lives were consecrated to the service of the sovereign mistress of truth.

An occasion of this kind has recently befallen us. Geological and biological science mourn the loss of Professor Albert Gaudry, foremost of the modern school of French paleontologists, a man of remarkable and versatile talents, in-

${ }^{1}$ Presented before the American Society of Vertebrate Paleontologists at the Baltimore meeting, December 30, 1908. 
vestigator, teacher and author of far-reaching influence, and not less distinguisked as a naturalist than universally beloved for his sweet simplicity of character and attractive personality. In him were happily combined that temper of mind and delicate sensitive spirit which proclaimed him not only as a fine type of the cultured scientific gentleman, but revealed him likewise as an homme de cceur, rich in human sympathy. Greatly as we deplore his loss, we may be glad that such a shining exemplar has graced our science. It is pleasing to contemplate him as a naturalist and interpreter of nature, but better still as a humanist. We honor him for his devoted service, we revere him for the lofty ideals he realized as a man. Much is expressed in the title by which his pupils and colleagues scattered over two continents were wont to address him: maître vénéré. His predominant trait was rightly characterized in an address delivered by his successor in the museum, Professor Boule, on a memorable occasion in the spring of 1903: "L'essence de votre nature, cher maître, c'est la bonté même." All who have enjoyed the privilege of personal acquaintance with the late president of the institute will concur in that sentiment.

The main facts in the life history of Professor Gaudry are briefly told. Born at SaintGermain-en-Laye, near Paris in 1827, eldest son of a well-known advocate, as a youth fond of natural history pursuits and amateur collector of fossils at Montmartre, awarded the degree of doctor of science at the age of twenty-five and appointed assistant professor of paleontology at the Paris Museum the following year, we find him undertaking his first serious work as a naturalist whilst engaged on a scientific mission to the Orient and islands of the Egean in 1853. His first publications date from the same year, and at this time he began his long-continued and classic studies of the late Tertiary vertebrate fauna at Pikermi in Attica. The results of this work, published 1862-7, under the title of "Animaux fossiles et géologie de l'Attique," together with its sequel on fossil vertebrates from Mont Léberon, won for him recognition as a leader in his special field, and constitute probably his most enduring monument in the province of descriptive paleontology. Other technical memoirs followed, among which it will suffice to mention those on Actinodon (1887), Dryopithecus (1890), pythonomorphs (1892) and Patagonian vertebrates, the last subject being one upon which he was still engaged at the time of his death, on the twenty-seventh day of November, 1908.

Excellent as are these special monographs, it is through his more popular, or at any rate less strictly technical, or perhaps we should say more broadly philosophical, writings, that Gaudry's name is most widely known both among his own countrymen and abroad. These brilliantly written essays, published in tripartite series during the years 1878-96, the first having for title "Les Enchaînements du monde animal," have exercised an incalculable influence in spreading evolutionary ideas and inculcating sound notions of paleozoology. It has been said that a philosopher is always something of a "poète manqué." This quality on the part of the author is strongly marked in the three volumes in question, and manifests itself not only in style, but in ideas, not only in the main theme under discussion, but in many a charming and naïve excursus, the effect of which is to make his work most exhilarating reading. His object is to present, as he tells us in one place, some things to instruct the mind, and yet others to satisfy the soul. And we must admit that he succeeds very well in both these aims. He was artist to this extent at least, that he sought in nature an ideal standard of truth and beauty, and made that standard effective in all human relations.

To the typical French mind, as to the ancient Greek, is commonly attributed a quick and accurate intuition, facile power of generalization, and a fondness for broad, comprehensive views as applied to any subject. Professor Gaudry well exemplified these racial characteristics. An analyst so far as involves the merely mechanical collection of facts, his genius consists in synthesis, in the rational coordination of his material after it has been laboriously brought together. In the early days of evolutionary discussion he incurred 
reproach for being a too brilliant theorist. Time has since justified his keen sense of discrimination, his rigid intellectual candor, and subtlety in drawing right conclusions, not only in those momentous issues, but in most of his later philosophical writings. His work obviously has enduring qualities; his positive results are gained for all time, and become the heritage of science.

One further feature deserves to be pointed out. Professor Gaudry was always consistently opposed to the idea of following a scientific pursuit from primarily mercenary motives. He warns young men of the necessity of cultivating higher ideals of their chosen calling. His words seem to reecho those of Francis Bacon, who long ago complained that "men have entered into a desire of learning and knowledge, sometimes as if there were sought in knowledge a shop for profit and sale; and not a rich storehouse for the glory of the Creator and the relief of man's estate." On the other hand, his career reminds us more emphatically than any precept, that in order to attain the repose and exaltation of soul that come after a lifetime of worthy effort and resources nobly expended-“ "it is worth while in the days of our youth to strive hard for this great discipline; to pass sleepless nights for it, to give up to it laborious days; to spurn for it present pleasures; to endure for it afflicting poverty; to wade for it through darkness, and sorrow, and contempt, as the great spirits of the world have done in all ages and all times."

Finally, no truer thing could be said of Gaudry than one of the most graceful and talented of French writers-Flaubert-said of himself: "Je fais tout ce que je peux pour élargir continuellement ma cervelle et je travaille dans la sincérité de mon cœur; le reste ne dépend pas de moi."

\section{R. EAstman}

HARVARD University

\section{SCIENTIFIC NOTES AND NEWS}

Mr. Alexander Agassiz and Professor Theobald Smith have been appointed delegates from
Harvard University to the Darwin Celebration at Cambridge University, England, in June, 1909.

The Académie Royale de Médecine de Belgique, at its meeting of December 26, last, elected Dr. Charles S. Minot, of the Harvard Medical School, a foreign corresponding member of the academy.

M. P. VILLARD has been elected to succeed M. Mascart as a member of the Paris Academy of Sciences, in the section of physics.

Dr. Henry E. Crampton has been appointed curator of the department of invertebrate zoology in the American Museum of Natural History, to fill the place made vacant by the resignation of Dr. William M. Wheeler. He will retain an official connection with Columbia University, where he now is professor of zoology in Barnard College. Dr. Frank E. Lutz, investigator in the Station for Experimental Evolution of the Carnegie Institution, has been appointed an assistant curator in the museum. Dr. Alexander Petrunkevitch has become officially connected with the museum as honorary curator of the Arachnida.

President Eliot has purchased a house on Brattle Street, Cambridge, which he will occupy after leaving the residence provided by Harvard University for the president.

Dr. H. C. Chapman, professor of the institutes of medicine and medical jurisprudence at Jefferson Medical College, and for thirtytwo years a member of the faculty, has resigned, his resignation to take effect in May next.

Governor Guild, of Massachusetts, has been elected president of the American Forestry Association to succeed President Wilson.

Professor Robert Koch has been elected a president of the German Central Committee for the Prevention of Tuberculosis, in the room of its founder, the late Herr Friedrich Althoff, ministerial director of the Prussian Education Office.

Dr. and Mrs. W. A. Murrill are in Jamaica to study and collect fungi in the interests of the New York Botanical Garden. 